\title{
EPIDEMIOLOGY AND PLACE: A SPATIAL AREA FOR HEALTH ANALYSIS
}

\author{
M. J. V. F. LEITE* , A. DANTAS and A. G. RONCALLI \\ Federal University of Rio Grande do Norte \\ jalilaleite@ufrnet.br*
}

Articlet received March/2015 and accepted in December/2015

DOI: $10.15628 /$ holos.2015.2854

\section{ABSTRACT}

The authors present a theoretical discussion related to spatial areas used in Epidemiology, analysing their theoretical and methodological strengths and weaknesses in the recognition of social determinants of health. Some territorial divisions were defended as alternative scales because of homogeneity and accuracy characteristics, and because of their particular criteria of definitions, while recognizing the necessity to overcome some challenges related to the concepts, research designs and access to data available in these scales.

KEYWORDS: Epidemiology, Health analysis, Place, Spatial area, Territory.

\section{EPIDEMIOLOGIA E TERRITÓRIO: UM RECORTE PARA ANÁLISE DE SAÚDE}

\section{RESUMO}

Os autores fazem uma discussão teórica relacionada aos recortes espaciais utilizados na epidemiologia, analisando suas fragilidades e potencialidades teóricometodológicas no reconhecimento da determinação social do processo saúde e doença da população. Algumas divisões territoriais são defendidas como escalas alternativas devido às suas características de homogeneidade, precisão e critérios específicos de definição, sem deixar de reconhecer a necessidade de superar alguns desafios relacionados aos conceitos, desenhos de pesquisa e acesso aos dados disponíveis nestas escalas.

PALAVRAS-CHAVE: Epidemiologia, Análise de Saúde, Território, Área Espacial. 


\section{INTRODUCTION}

The search for a spatial area in order to identify health status has always been present throughout the evolution of epidemiological knowledge. However, it is permeated by the construction of several concepts which are implicated in this decision.

These concepts are related to the understanding of the health and disease process, initially strongly focused on the positivist view that takes the hegemonic disease theory as the centre of its reflections.

Later, this view is extended with the understanding of social conditions' influence on the health situation of the population, initially induced by the inclusion of the risk concept, which in spite of providing a good reference for health interventions, it also suits the disease theory in the same way to strengthen the prevention of certain specific diseases.

Only later, this view of risk also extends through strengthening the health promotion concept, which is related to the broader concept of the health and disease process, in which social factors are decidedly understood as determining the health condition or disease in the population.

On the other hand, the understanding of space was developed as an insight into what is seen as incomprehensible and that determines everything, and also as a health risk. More recently, some approaches advocate the understanding of space as a territory by using it as a category of social analysis and, consequently, of health.

Therefore, supported by the construction of the concept of space in Geography, epidemiology researchers and also geographers who focus on this issue, do not forego the understanding of space as a determinant of the health condition. However, studies have shown that sometimes researchers have lacked these theoretical and methodological elements which allow them to make sure that this knowledge, especially in the aspect that they are most accustomed to, the "certainty" offered by quantitative studies.

Most of these problems relate to the challenge of identifying a spatial area that permits using this new approach - the analysis of health status based on territory as a category of analysis. As result of this, in this article we propose a dialogue with the authors who are discussing this topic in an attempt to offer some theoretical clues to guide research in this area.

\section{CONCEPTS RELATED TO SPACE AND THE HEALTH AND DISEASE PROCESS}

Geography, despite nowadays having space to discuss and object activity, has developed different concepts for its understanding over the years. This evolution begins with the idea that space could be reduced to its physical dimensions and cartographic overlapping between landscape and space, becoming synonymous (BOUSQUAT; COHN, 2004). Thereafter, the current understanding of space territory has been developed from human aggregation with the landscape, that is, the understanding of spaces as systems of objects and actions (SANTOS, 2009).

Regarding this, Bonfim and Medeiros (2008) emphasize that space is designed as a result of a sum and synthesis, always redone, of society with the landscape through spatiality.

Tunstall, Shaw and Dorling (2004) claim that it is crucial to understand the difference between place and space. The space describes where the phenomenon is located and the place 
describes what the location is. They also state that public health studies concern where people live, work or die, omitting some considerations about the place.

Moreover, the authors caution that it is necessary to understand that the parcel of health variations observed in places can be attributed to the characteristics of the people who live in those places, and other parcels to the effects of those places on people's health (TUNSTALL, SHAW, DORLING, 2004; CUMMINS et al., 2007; FROHLICH, 2007).

In this regard, Arcaya et al. (2012) argue that in contrast to the place perspective that uses geographic information to form groups, the use of the space perspective defines each observation according to their proximity with other observations, ignoring potential significant similarities that are usually shared with geographic and political boundaries.

Other concepts also related to space are conformed in this process. The landscape, previously considered synonymous with space, is understood by Santos (2009) as a set of concrete forms and materials, inherit relations between man and nature. However, spaces are interpreted as being associated not only to the location in space, but with the idea of human presence, explained both by its spatiality and by its temporality (MONKEN, BARCELLOS, 2005).

The understanding of territory as a synonym for space has its theoretical framework based on the concept of technique. In this regard, Santos (2008) and Silveira (2006) point to its importance as a set of social and instrumental means whereby man realizes his life, production, and at the same time, creates their space for understanding space as a social process. Thus, the technique is one element which contributes to space being understood as territory.

Heidegger (2006), through his reflections on the technique, goes further by saying that the positive view of the technique lies in knowing its essence, which is not something technical. Thus, he states the need to relate it beyond the technique, toward its instrumental and anthropological determination. It is in this aspect that the technique is a condition for working with the concept of space in the conception of territory. As to use the category of territory, it is necessary to understand the technique as an integral and essential part of the territory and more than that, as something that is not easily accessible.

In this regard, Barcellos (2003) states that if the disease is considered an individual manifestation, the living conditions are manifestations of the place, even if there are limitations of the influence of place due to individual characteristics.

The role of space in determining the health and disease process in the population has been studied since ancient times, with the first work being attributed to Hippocrates (480 B.C.) describing the environmental effects on the health of individuals and populations - Air, Water and Places (CAIRUS, 2005; REGO, 2006; SCLIAR; ALMEIDA FILHO; MEDRONHO, 2011).

In another classic study, John Snow (1854) brought a contribution to the understanding of this relationship to determine the causality of cholera from drawing up a map showing the distribution of cases in London. This map showed the points of the sewage network, the water pumps, the streets with their houses, buildings, and residences with the occurrence of deaths (SNOW, 1999; STEVEN, 2008; BONFIM; MEDEIROS, 2008). This study was considered a theoretical framework to understand the role of space in health and disease process for Epidemiology, and allowed Snow to suspect the transmission of cholera through the water without availability of microbiological knowledge. 
In the area of Geography, important theoretical concepts relating to this discussion were prepared at the end of the 1930s. The Russian parasitologist Evgeny Pavlovsky worked out the Theory of Natural Disease Focus, also known as Theory of Natural Nidality of Communicable Diseases, which attributed the eventual production of outbreaks to man through their actions on nature.

Thus, he is considered the first author to relate the spatial sense in contemporary epidemiology. His theory of ecological nature established the concept that space was the scenario in which the infectious agent circulated (VIEITES; FREITAS, 2007; BALASHOV, 2010).

In the same period, the French geographer Maximilien Sorré defended the relevance of man's action in the formation and alteration of the pathogenic complex, observing the existence of the relationship between the disease and the geographical, physical and biological characteristics of the place where they are, laying the foundation of Medical Geography (VIEITES; FREITAS, 2007).

To worry about the operation of its proposed pathogenic complex, Sorré introduced the discussion on the element of time and the consequent historical character of this relationship, and also discussed the limits and uses of morbidity and mortality maps, stating its importance in understanding the pattern of disease distribution. In this respect, he introduced a discussion related to cartography and scales, relating the importance of studying the distribution of diseases through maps and their relation to health services (BOUSQUAT; COHN, 2004).

In Brazil, some theoretical contributions representing initial advances in the analysis of the relationship between space and health were prepared by researchers Samuel Pessoa, Josué de Castro, Luiz Jacintho Silva and Milton Santos.

Samuel Pessoa studied endemic diseases transmitted by vectors around Brazil in the 1970's, especially schistosomiasis and Chagas' disease, and defended the relationship of these diseases with the environmental characteristics of the areas where they occurred and with the socioeconomic conditions of the populations involved (VIEITES; FREITAS, 2007; VIEITES, 2014).

The contribution of Josue de Castro is evidenced by the publication of his pioneering work - Geography of Hunger, in 1946. This publication has strongly contributed to the discussion of a non-transmissible event hunger - and with one definition of space not reduced to the triad agent, host and environment, usual in communicable disease research. On the other hand, it was a pioneering work in the complaint of poor social conditions for much of the Brazilian population (CZERESNIA, RIBEIRO, 2000).

Luiz Jacintho is considered one of the first authors in the medical field to use the concept of geographical space in epidemiological studies. Through his studies related to schistosomiasis and Chagas' disease conducted in the 1980's, he established an explanatory link between biological and social dimensions of these diseases (VIEITES, 2014).

Milton Santos developed geographic concepts strongly embedded in public health, especially the concept of territory. In this case, territory is understood as object systems and action systems, or a set of forms and functions, inherit in relations between man and nature, and not only interpreted by the location in space, but by the idea of human presence (MONKEN; BARCELLOS, 2005; GONDIM, 2008; SANTOS, 2008; SANTOS, 2009; FARIA; BORTOLOZZI, 2009). 
The incorporation of the concept of territory in Public Health is true not only for enabling research on ownership and domination of space and its relation to health, but because it is a concept that allows operability for the use of a space category in the planning and evaluation of health actions (FARIA, BORTOLOZZI, 2009).

\section{THE TERRITORIAL DIMENSIONS AND THE HEALTH AND DISEASE PROCESS}

The size and shape of the space to be analyzed produces interference in the results of epidemiological studies. This can interfere in the understanding of the health and disease process in this space. An initial challenge presents itself at the time that is needed to choose a territorial dimension to enable analysis of data based on the social determinants of health. To ensure this, in addition to geographical features of the areas, it is necessary to evaluate the possibility of this space to highlight the aspects of social relations that are inserted there (LEITE, 2015).

Silveira (2006) highlighted this issue by stating that the division of spaces, revealing its nature, constitution and relations is a great challenge to researchers, with not only the consideration of Euclidean distances being essential, but also human distances related to time and human activity.

With regard to the particularities of geographical scales in epidemiological analysis, Merlo (2011) states the need to reflect first on the selection of a scale that best matches the contextual factors that influence individual health or behavior related to the health studied.

Traditionally, despite the fact that health or illness occurs in social contexts, most epidemiological research on health determinants has used individualized data (DIEZ ROUX, 2009). With this view, it has been the understanding that the disease occurs in individuals, and thus has biological expression.

On the other hand, the existence of representative factors of living conditions is also admitted, determined by the socioeconomic and political structure of human societies, which can only be demonstrated through studies using aggregate variables (AQUINO et al., 2011).

With regard to this issue, Buss and Pellegrini Filho (2007) admitted that there is a conceptual and methodological challenge in distinguishing the determinants of health of individuals and of groups or populations. They claim that some factors are important in explaining different health statuses of individuals, but they do not explain the differences in a society or between groups of society. These authors emphasize that nowadays, the biggest challenge in understanding the relationship between social determinants and health is to establish a hierarchy of determinations between more general, social, economic, and political factors, and meet the mediations through which these factors focus on the health status of groups and individuals.

Thus, ecological studies are now developed more often with the intention of understanding the relationship between space and health and the disease process of population.

This is justified based on the fact that some factors that affect health and illness can only be identified at the ecological level, and the challenge of Epidemiology is precisely in using the population level approach, not only as a subsidy from the individual level, but as another level of organizational reality, with specific and intrinsic properties (SANTOS, BARCELLOS, 2008). 
In this regard, Aquino et al. (2011) states that they understand that the disease occurs in individuals and therefore has biological expression, but admit the existence of representative factors of life conditions, determined by the socioeconomic and political structure of human societies, which may only be demonstrated through studies using aggregate variables.

With regard to the particularities of geographical scales in epidemiological analysis, Merlo (2011) states the need to reflect first on the selection of a scale that best matches the contextual factors that influence individual health or behavior related to health.

In accordance with these ideas, the use of small areas has been a good strategy for the study of social determinants of health in an attempt to obtain more homogeneous results. Its use allows for a deeper understanding of geographical patterns with the concept of territory and identification of clusters of health inequalities, essential in identifying local inequalities, often masked when estimates are grouped into larger areas (BARCELLOS, 2003; ROJAS, 2008; BORREL et al., 2010).

It is important to highlight that the possibility of using small areas in epidemiological studies are limited by the availability of data related to them, leaving researchers to the decision of using territorial divisions adopted by the institutions, usually defined by geopolitical and administrative interests (BARCELLOS, 2003; MERLO, 2011).

In this regard, Tunstall, Shaw and Dorling (2004) state that in studies using different scales of analysis, the significance of these scales has been superficially theorized, especially in relation to small areas. Thus, it has been argued that health in small areas is more often a product of its individuals and health in larger areas is widely accepted as a product of its history, culture, capital, economy, ethnicity, religion and other social factors. In this sense, they claim that different types and scales of places can play different roles in health and that this relationship is still conceptually and empirically unclear.

In Brazil, most epidemiological research uses the classical divisions, while territorial boundaries allow for good understanding and availability of data at different scales, being traditionally related to the country, the major regions, the units of the federation, and the microregions and municipalities.

The planning and management of health care for the Brazilian Healthcare System is carried out based on health regions, defined from the classic territorial divisions - groups of municipalities. Similarly, health information systems provide their data based on official territorial units.

The Brazilian Institute of Geography and Statistics (IBGE) has recently used other territorial divisions in their research - census tracts, weighting areas and urban regional division beyond the traditional administrative and political divisions of Brazil. These new areas, depending on the availability of data and cartographic databases for handling, have begun to be more frequently used by Brazilian Epidemiologists (LEITE, 2015).

Census tracts are territorial units established by IBGE for cadastral control of Brazilian census. They consist of contiguous areas, respecting the limits of political-administrative and legal division of the urban and rural and other territorial structures of interest, in addition to being an appropriate scale for implementation of the census (BRASIL, 2013a).

The weighting areas were defined by the IBGE census for 2010. It is formed by a mutually exclusive group of contiguous census tracts, with a minimum size of 400 occupied households in 
the sample, except for the municipalities that did not reach this total. In this case, the municipality itself was considered a weighting area (BRASIL, 2013a).

The Urban Articulation Regions make up a new structure of urban-regional division defined based on criteria that combine the process of urbanization and national integration with the vertical structures that establish networking relationships and strengthen cities and urban agglomerations. These elements were considered essential for interconnection management, infrastructure and productive activities (BRASIL, 2013b).

Based on these issues, the Urban Regional Division consists of three types of regions: 14 Expanded Urban Associated Regions (Figure 1); 161 Intermediate Urban Associated Regions (Figure 2) and 482 Immediate Urban Associated Regions (Figure 3) (BRASIL, 2013b).

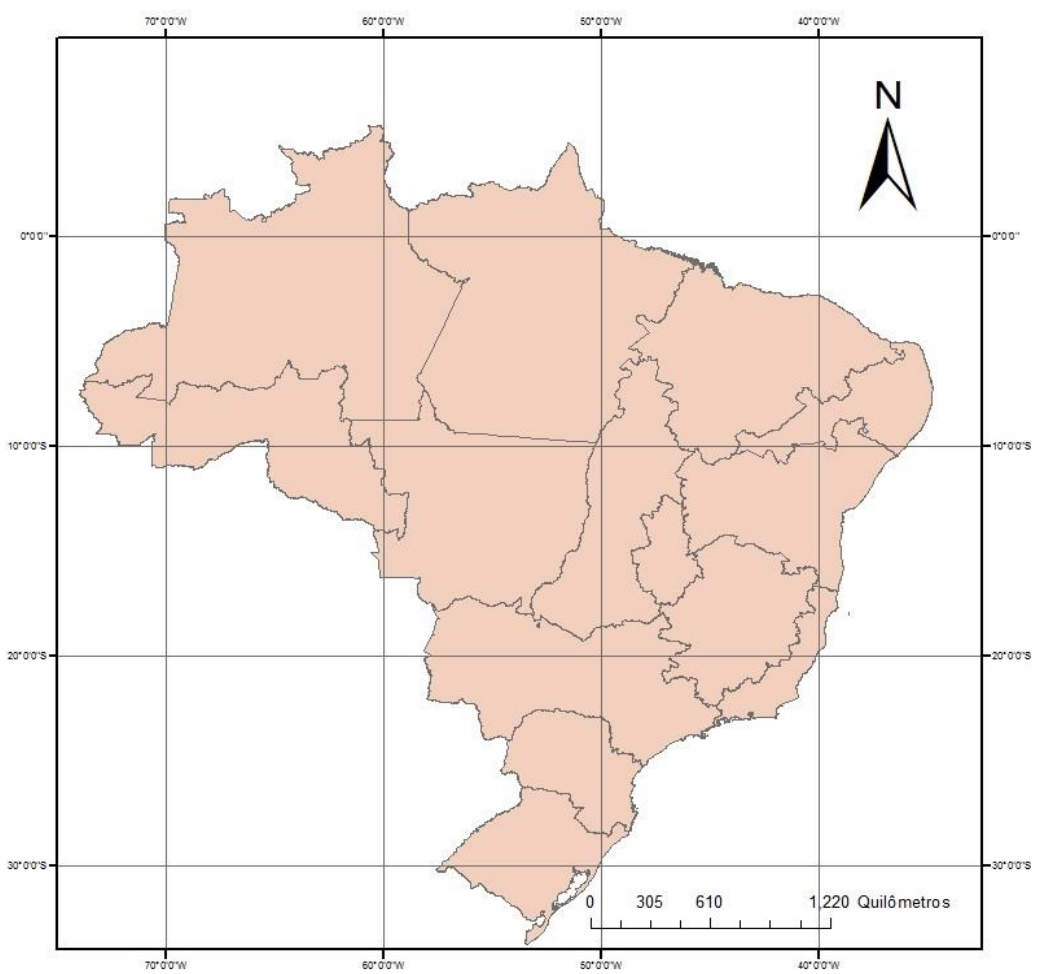

Figure 1 - Urban Regional Division, with the 14 Expanded Urban Associated Regions. 


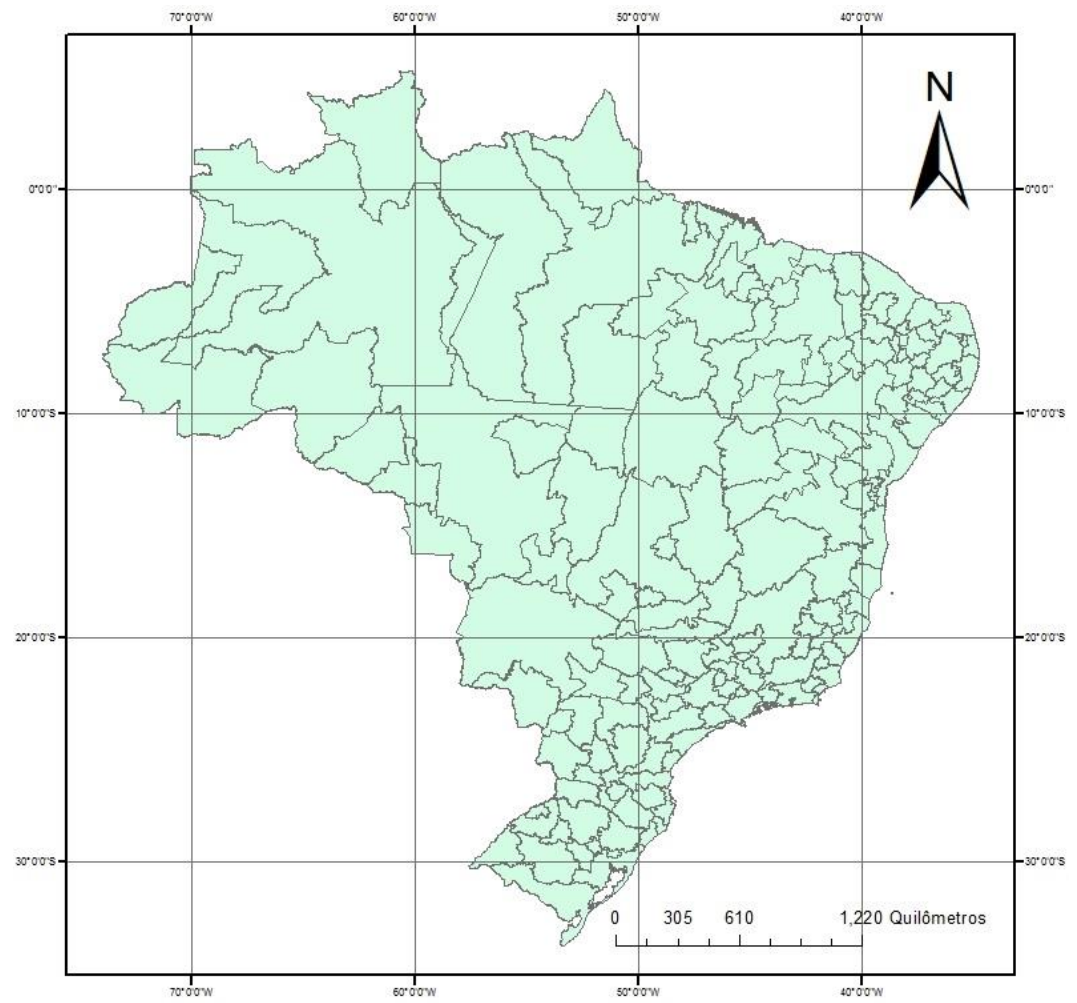

Figure 2 - Urban Regional Division, with the 161 Intermediate Urban Associated Regions.

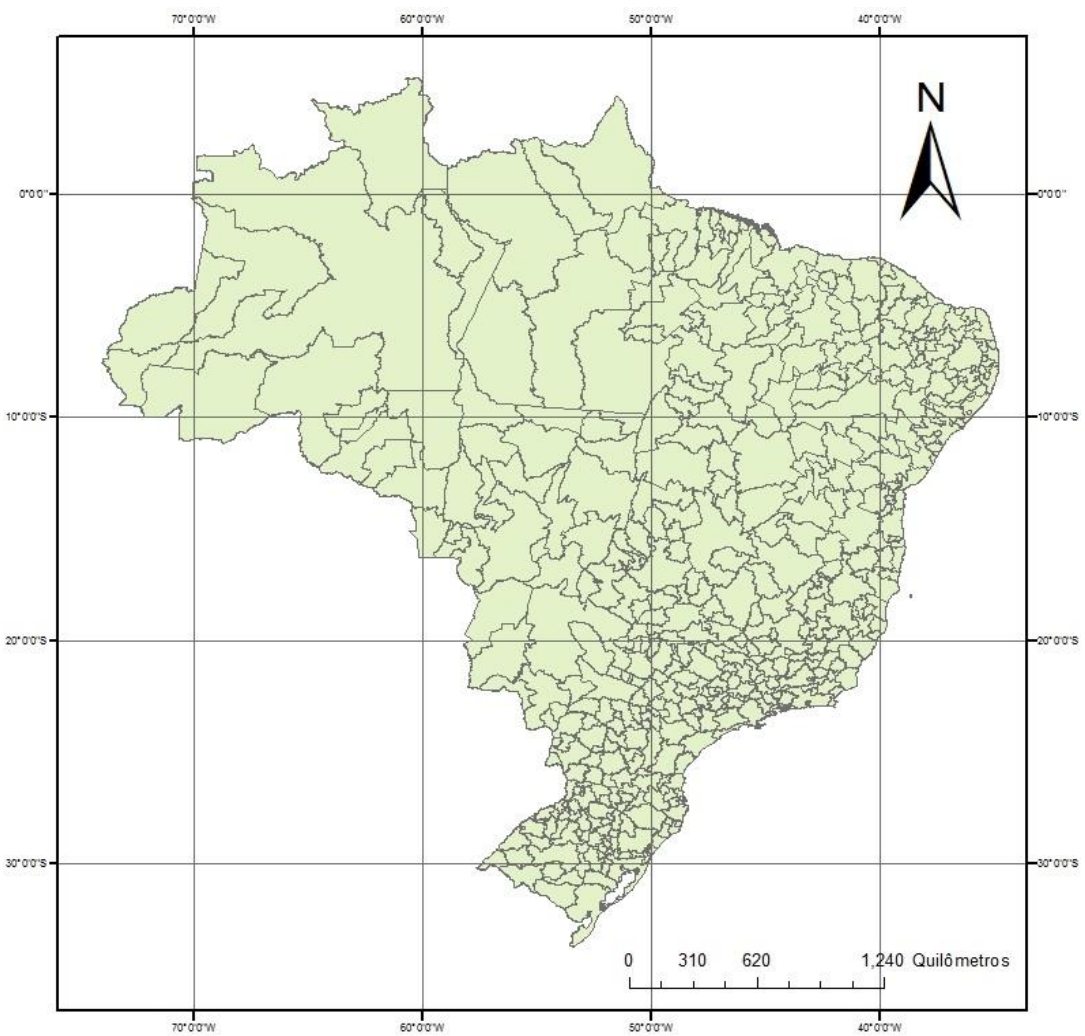

Figure 3 - Urban Regional Division, with the 482 Immediate Urban Associated Regions. 
The use of these new territorial divisions in epidemiological studies that aim to analyze the social determinants of health can promote a better analysis of the health and disease process in the context of social inequality present in Brazilian population. Some researchers have shown this; for example, Leite (2015) in a study in which these territorial divisions were analyzed to identify the random fluctuation of socio-economic indicators related to social determinants of health concluded that the form of definition and scale of the territorial divisions should be taken into account in the assessment of these effects.

Public Health, specifically Epidemiology, tries to identify a spatial area in which the healthdisease process is represented in its expanded concept, with identification of social determinants of health, and searches for a scale that is as homogeneous as possible. Census tracts, weighting areas or urban regional division with different forms of divisions may be an alternative.

The use of census tracts and others as spatial slices for health analysis based on a territory category involves efforts to overcome some challenges related to the concepts and designs of theoretical and methodological research.

Another challenge is the access of data available in this scale, considering that most ecological studies are conducted using secondary data. Sources of information are necessary to enable deciding the units and observation scales (ROJAS, BARCELLOS, 2003). In this case, it points to the need to reorganize health information systems that enable identifying census tracts in their forms and databases.

It is also necessary to expand the number of studies that aim to develop new interpretative models of health and illness in space and expand the analysis of health data, as well as their frequency and spatial distribution toward an analysis of the implications of the places in this situation.

Finally, we emphasize the importance of this discussion to approach the frontiers of knowledge between Geography and Epidemiology, with the main current challenge of Epidemiology being to find methods and techniques that reflect the reality of places as much as possible.

\section{REFERENCES}

1. AQUINO, R. et al. Estudos ecológicos (desenho de dados agregados). In: ALMEIDA FILHO, N.; BARRETO, M. L. (Org). Epidemiologia \& saúde: fundamentos, métodos e aplicações. Rio de Janeiro: Guanabara Koogan, 2011, p. 175-185.

2. ARCAYA, M. et al. Area variations in health: a spatial multilevel modelling approach. Health place, v. 18, n. 4, p. 824-831, 2012.

3. BALASHOV, Y. S. The 70th anniversary of E. N. Pavlovsky's concept of natural nidality of human diseases. Entom. Rev., v. 90, n. 4, p. 533-536, 2010.

4. BARCELLOS, C. Unidades y escalas en los análisis espaciales en salud. Rev. Cub. Salud Pública, V. 29, n. 4, p. 307-313, 2003.

5. BONFIM, C.; MEDEIROS, Z. Epidemiologia e Geografia: dos primórdios ao geoprocessamento. Espaç. Saúde, v.10, n.1, p. 53-62, 2008.

6. BORREL, C. et al. Inequalities in mortality in small areas of eleven Spanish cities (the 
multicentre MEDEA project). Health place, v. 16, n.4, p. 703-711, 2010.

7. BOUSQUAT, A.; COHN, A. A dimensão espacial nos estudos sobre saúde: uma trajetória histórica. Rev. História, Ciências, Saúde, v. 11, n. 3, p. 549-568, 2004.

8. BRASIL. Instituto Brasileiro de Geografia e Estatística - IBGE. Metodologia do censo demográfico 2010. Rio de Janeiro: IBGE, 2013a. Disponível em: <www.ibge.gov.br $\geq$. Acesso em: 01 mar. 2015.

9. BRASIL. Instituto Brasileiro de Geografia e Estatística - IBGE. Diretoria de Geociência. Coordenação de Geografia. Divisão Urbano Regional. Rio de Janeiro: IBGE, 2013b. Disponível em: <www.ibge.gov.br>. Acesso em: 01 mar. 2015.

10. BUSS, P. M.; PELLEGRINI FILHO, A. A Saúde e seus determinantes sociais. Physis (Rio J.), v. 17, n. 1, p. 77-93, 2007.

11. CAIRUS, H. F. Ares, águas e lugares. In: CAIRUS, H. F.; RIBEIRO JÚNIOR, W. A. Textos hipocráticos: o doente, o médico e a doença. Rio de Janeiro: FIOCRUZ, 2005. p. 91-129. (Coleção História \& Saúde).

12. CUMMINS, S. et al. Understanding and representing 'place' in health research: a relational approach. Soc. Sci. Med., v. 65, n. 9, p.1825-1838, 2007.

13. CZERESNIA, D.; RIBEIRO, A. M. O conceito de espaço em epidemiologia: uma interpretação histórica. Cad. Saúde Pública, v. 16, n. 3, p. 595-617, 2000.

14. DIEZ ROUX, A. V. Next steps in understanding the multilevel determinants of health. J Epidemiol. Community Health, v. 62, n. 11, p. 957-959, 2009.

15. FARIA, R. M.; BORTOLOZZI, A. Espaço, território e saúde: contribuições de Milton Santos para o tema da geografia da saúde no Brasil. Rev. RA'E GA, n. 17, p. 31-41, 2009.

16. FROHLICH, K. L. et al. Understanding place and health: a heuristic for using administrative data. Health Place, v. 13, n. 2, p. 299-309, 2007.

17. GONDIN, G. M. M. Espaço e Saúde: uma (inter) ação provável nos processos de adoecimento e morte em populações. In: MIRANDA, A. C. et al. Território, ambiente e saúde. Rio de Janeiro: FIOCRUZ, 2008. p.57-75.

18. HEIDEGGER, M. A questão da técnica. In: Ensaios e Conferências: Martin Heidegger. Trad. LEÃO, E.C., FOGEL, G.; SCHUBACK, M.S.C. 7 ed. Petrópolis: Vozes; Bragança Paulista: São Francisco, 2006, p. 11-38. (Coleção Pensamento Humano)

19. LEITE, M.J.V.F. Efeito de diferentes divisões territoriais na flutuação aleatória de indicadores socioeconômicos relacionados à determinação social da saúde. 2015. 83 f. Tese (Programa de Pós-graduação em Saúde Coletiva) - Universidade Federal do Rio Grande do Norte, Natal, 2015.

20. MERLO, J. Contextual influences on the individual life course: building a research framework for social epidemiology. Psychosoc. Interv., v. 20, n. 1, p. 109-118, 2011.

21. MONKEN, M.; BARCELLOS, C. Vigilância em saúde e território utilizado: possibilidades teóricas e metodológicas. Cad. Saúde Pública, v. 21, n. 3, p. 898-906, 2005.

22. REGO, S. Convite a (re)leitura dos textos hipocráticos. Cad. Saúde Pública. v. 22, n. 1, p. 228$235,2006$. 
23. ROJAS, L. I.; BARCELLOS, C. Geografia y salud en América latina: evolución y tendencias. Rev. Cubana Salud Publica, v. 29, n. 4, p. 330-343, 2003.

24. ROJAS, L. I. La diferenciacion territorial de la salud em la recuperación de los contextos. In: BARCELLOS, C. A geografia e o contexto dos problemas de saúde. Rio de Janeiro: ABRASCO: ICICT; EPSJV, 2008, p. 87-106.

25. SANTOS, S.M., BARCELLOS, C. A vizinhança como contexto: resgatedo nível ecológico na determinação de saúde e bem estar. Cap. 12. In: MIRANDA et al. Território, Ambiente e Saúde. Rio de Janeiro: FIOCRUZ, 2008, p.217-236.

26. SANTOS, M. Sistema de objetos, sistemas de ações. In: Técnica, espaço, tempo. 5. ed. São Paulo: EDUSP, 2008. p. 85-111.

27. SANTOS, M. O espaço: sistemas de objetos, sistemas de ação. In: A natureza do espaço. 4. ed. 5 reimp. São Paulo: EDUSP, 2009. p. 61-87.

28. SCLIAR, M.; ALMEIDA FILHO, N.; MEDRONHO, R. Raízes históricas da epidemiologia. In: ALMEIDA FILHO, N.; BARRETO, M. L. (Org). Epidemiologia \& Saúde: fundamentos, métodos e aplicações. Rio de Janeiro: Guanabara Koogan, 2011, p. 5-23.

29. SILVEIRA, M. L. O espaço geográfico: da perspectiva geométrica à perspectiva existencial. Rev. GEOUSP Espaço Tempo, n. 19, p. 81-91, 2006.

30. SNOW, J. Sobre a maneira de transmissão do cólera. 2. ed. São Paulo: Hucitec, 1999.

31. TUNSTALL, H. V.; SHAW, M.; DORLING, D. Places and health. J. Epidemiol. Community Health, v. 58, n. 1, p. 6-10, 2004.

32. STEVEN, J. O mapa fantasma: como a luta de dois homens contra o cólera mudou o destino de nossas metrópoles. Trad. Sérgio Lopes. Rio de Janeiro: Zahar, 2008.

33. VIEITES, R. G. Os estudos de Samuel Pessoa e Luiz Jacintho da Silva e a geografia médica no Brasil. Hygeia, v. 10, n.18, p. 140-148, 2014.

VIEITES, R. G.; FREITAS, I. A. Pavlovsky e Sorre: duas importantes contribuições à geografia médica. Ateliê Geográfico, v. 1, n. 2, p. 187-201, 2007. 